\title{
Investigating the Relationship between Engagement and Achievement in Iranian Online English Classes in the COVID-19 Era
}

\section{Monireh Mokhtarzadeh ${ }^{1 *}$}

\section{* Correspondence: \\ mokhtarzadehmonireh59@gamil.com \\ 1. Birjand University, Iran}

Received: 3 August 2021

Revision: 21 October 2021

Accepted: 19 November 2021

Published online: 20 December 2021

\begin{abstract}
Online education, as a type of distance education, has attracted the attentions of administrators, instructors, and students in recent decades. In the midst of the Covid-19 epidemic, online education has become an unavoidable need. Students' participation in such programs may have an impact on their learning and achievement. The current study looked at the link between engagement and achievement in online classrooms. As a result, the study used a correlational design to address the research questions using Dixon's Online Student Engagement Scale and a researcher-created achievement exam. The questionnaire was developed in 2015 and comprises four categories and 19 items on a seven-point Likert scale. In 2020, the questionnaire was modified with Google Form and distributed to 297 students enrolled in general English courses via a university LMS. The second instrument was a 40-item test of reading comprehension developed by the researcher. The examination was created on the basis of reading theories and was given as a final exam. The one-sample t-test findings indicated that students' achievement and engagement levels are adequate. Quantile regression revealed a strong link between top achievers' engagement and achievement. However, bivariate correlation revealed no statistically significant link between typical students' engagement and achievement. However, students' level of engagement perception was satisfactory. The concept of engagement applies to high achievers but not to ordinary or low performers, making measurement error possible.
\end{abstract}

Keywords: online education; engagement; engagement perception;

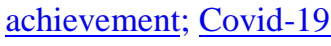




\section{Introduction}

The effect of information technology on human life is immense and its role in education cannot be subsided. In the current scenario of COVID 19 pandemic, the contribution of information technology has gained momentum due to closure of educational institutions that raises challenges for students' learning. During this quarantine time information technology is serving the solution for the ongoing learning process through innovative and learning management systems (Nassoura, 2020). It has provided opportunity for educators to implement IT solutions for teaching as well as evaluation for the completion of course work of students. The efforts of stakeholders namely teachers, students, and institutional administrators are on for the optimal use of the technology and efficient learning process (Pérez, 2020). The ultimate goal is to minimize the learning gap that arouses due to lockdown. Educational institutions and students across the world have accepted and appreciated the online platform of learning. The reasons of this acceptability are ease of use, learning flexibility, and controllable environment.

However, despite its multiple advantages there are quite a few limitations of e-learning such as social isolation, face to face interaction between teacher and student, and connectivity issues (Shrestha et al., 2019). E-learning has never been adopted and accepted as real learning or the formal mode of education before this ongoing pandemic that compelled to resort to electronic learning solution by world over (Al Kurdi et al., 2020). Now, at the hour of pandemic crisis, most of the educational institutions are exploring and approaching towards e-learning to make it easy for students to work out at new normal. Also, various e-teaching software are being explored by teachers or educators to bring maximum possible ease for their students (Alhazzani, 2020). As a matter of fact, as this e-learning wave is a recent development, teachers as well as students are in the process of adapting this new teaching and learning methodology. It is important to measure student satisfaction in education, where student satisfaction and student motivation are the results of student interactions with the educational environment in the form of students' perceptions of the educational services (Stoesse et al., 2015).

At this prevailing situation of virtual teaching and setting of new normal of teaching-learning methodology, it becomes all more important to get to know the opinion of learners and to explore learners' inclination towards this novel teaching methodology, such as their degree of adaptation and engagement if any they would like to suggest for the same or want to reject it altogether (Muller, 2020). As universities moved online in response to COVID-19, student engagement has been identified as a challenge (Farooq et al., 2020; Nickerson \& Shea, 2020; Perets et al., 2020) and very little research has examined the relationship between their engagement and achievements in a pandemic. Against such a backdrop, this study aims to examine the students' degree of engagement and their academic achievements through e-learning during COVID-19 lockdown period.

\subsection{Statement of the Problem}

Tertiary online classes during COVID-19 lockdown in Iran were not supplementary to traditional face-to-face courses but became the only way that students were able to "attend" classes. These online classes were conducted in an emergency, i.e., with limited time for planning how the teaching and learning resources should be organized (Badrkhani, 2021). Consequently, how students participate and perform when a major component of the learning experience is conducted via an online learning environment is still an open question (Song et al., 2017). The present study, therefore, used a correlational approach to investigate students' engagement and achievement with online courses in academic context during the COVID-19 pandemic. It can help to develop a more comprehensive picture of student online learning engagement to inform future policy and practice. This research is descriptive and the research questions are:

1. Are students' academic progresses in English language satisfactory?

2. To what extent do students perceive class participation?

3. Is there a significant relationship between active participation and academic achievement in the online English class?

\section{Literature Review}

Online education is a type of distance education that has been considered by educators and students for many years. Distance learning is conducted in a variety of ways. According to Wagner et al. (2003) in the 1800s, this type of education was employed through correspondence method. Distance learning was provided by radio in the 1920 s and by television in the 1930s. In 1993, online computer training began, which can be considered as the beginning of 
online training. In 1998, web-based training began. Lim et al. (2009) believe that the outcome of education can be a good indicator for evaluating the quality of distance education. The results of education are the amount of learning (cognitive variable) and academic satisfaction (emotional variable).

Since the outbreak of corona virus in Iran, in March 2020, the Iranian education system has turned to online education at all levels. This type of training has its own requirements. One of the effective factors in upgrading the effectiveness of this type of education is the active participation of students in the learning process. In this article, we will discuss the role of active participation in learning English in the online classroom. An overview of academic achievement and students' perceptions of class participation will also be provided.

Mitra and Le (2019) stated the level of success students achieve in their years at college has far-reaching implications for students' personal and professional lives, persistence in elected majors, perseverance in higher education, and their success in their future career. In universities nationwide, dissatisfaction with low performance in college classes is a serious problem (Horn, Peter, \& Rooney, 2002; Horn \& Premo, 1995). Research has shown a student's overall academic success, success in their future professional career, and even success in their personal life can be significantly and negatively impacted when the student's performance is low in courses designed to develop essential skills and introduce students to disciplinary studies (Seymour \& Hewitt, 1997; Tobias, 1990).

In order to contribute to students' achievement, online education requires educational institutions to reconsider their teaching methods and strategies so that education adapts better to the needs of students (Stocker, 2018). Yuan and Kim (2014) believe that education managers should make collective education possible in an online learning environment; because this type of education strengthens the relationship between teacher and student, and through this, student performance and academic satisfaction are improved. However, there are various factors involved in students' low performance beyond their level of engagement.

The research literature has identified technical challenges commonly experienced by distance learning students which specifically includes; (a) weak internet connection, (b) poor technical proficiency, (c) poorly trained faculty, (d) slow institutional technical support, and (e) incompatible devices (Qureshi, Khawaja, \& Zia, 2020). Proper administration of distance learning initiative requires a university to build an effective academic technology function, with resources and support for faculty and students (Rose \& Moore, 2019) to improve both student and teacher success in distance learning courses. This led the authorities to develop excellent Information Technology Services that provide technical support to students and faculty which includes: (a) providing free laptops to new students; (b) maintaining excellent learning labs; (c) managing all the technology on campus; (d) providing robust technical support to students, staff, and faculty; and (e) as an overall goal of acquiring quality for online instruction. All universities in Iran also provide training and support to students related to the university's LMS and all other technology students may encounter in any class across campus.

Besides providing technological infrastructures, the prerequisite for the success of online education, in addition to numerous educational variables, is the ability of teachers to adjust educational norms and review the management of time and method of teaching courses (Martins \& Nunes, 2016). Students expect teachers to create a sense of belonging in students in online education, as well as in face-to-face education, and to strengthen their learning (Loh et al., 2016). According to Allen and Zhang (2016), students in online education should develop the following abilities: having a passion for learning; strengthening their learning and perception base; preparing themselves cognitively for learning; developing problem-solving skills; and becoming self-motivated. The most prominent feature of adult learners is active learning and participation management, which ultimately leads to increased motivation. In contrast to this, Phillips (2005) believes that learning management must be created from the outside to lead to active student participation. He believes that participation based on external motivation becomes internal participation over time.

Maslach and Leiter (1997) derive the oldest concept of "active participation" from research on "emotional burnout." They have defined emotional burnout as reduced participation. Emotional burnout syndrome has three dimensions: emotional burnout, self-esteem, and personal development (Maslach et al., 2015). In later years, Schaufeli et al. (1996) extended these concepts to burnout, pessimism, and job inefficiency. Thus, in previous research, active participation was considered the opposite of emotional exhaustion, and was defined as giving importance to work and using all your strength and dedication to achieve a satisfactory result. When participation becomes weaker, we become tired, and participation turns into pessimism and efficiency into inefficiency, leading to burnout. From this perspective, burnout and the participation are two poles of a continuum. Of course, this does not mean that people with low levels 
of burnout will necessarily be actively involved in their work. Schaufeli et al. (2002) introduced a new concept of partnership that includes strength, sacrifice, and focus.

From Dixson's (2015) point of view, the definition of active participation is ambiguous. Kuh (2003) defines active participation as a student's effort in the learning process. He believes that the elements of active participation are: interaction (interaction with the content of the lesson, interaction with peers and teachers) and performance (achieving the desired goals). Dixson included these elements in his questionnaire called 'the Active Participation Scale for Online Learning.'

Lewis et al. (2011) have defined participation as: 'the extent to which thinking, emotions, and activities are involved in learning.' Connell et al. (1995) divide student participation into three categories: behavioral (persistence in learning, effort, and focus on learning); emotional (interest in learning) psychological (acceptance of challenges, independence, and participation in curricula). Reschly et al. (2017) believe that class participation refers to the grade and time spent on homework (lecturing, solving exercises, and group activities).

Khan et al. (2017) claim that educators face many challenges in strengthening students' active participation in online education. The most important challenge is that they want to use the same traditional teaching methods in online classes; this means that they do not change their teaching methods. In online teaching, teachers have a role beyond lesson design. They need to be clear about their work methods and educational expectations for students, give feedback to students, and correct their mistakes (Sheridan \& Kelly, 2010). Umbach and Wawrzynski (2005) concluded in their study that students, who are challenged scientifically by their teachers, could be more involved in the learning process.

According to Fisher (2010), students' previous experience in online education increases their active participation in such classes. In other words, students who have no previous experience and attend an online class for the first time may not be able to actively participate in the class. Fisher also believes that most students prefer traditional (face-toface) education to online education, as this is the only teaching method that students have experienced in high school or early college. In addition, Toplin (2000) and Hoffman and Ritchie (1997) have found in their research that some students cannot change their passive (teacher-dependent) learning habits. They often feel anxious and resist changing the way they teach, blaming their teachers. Layne et al. (2013) believe that students' individual characteristics such as disability or self-efficacy and resilience affect their ability to continue their education.

According to Dennen et al. (2007), active student participation is the extent to which the student thinks, comments, and interacts with the curriculum, other students, and his teacher. According to constructivist theory, this type of interaction is essential for learning (Bigatel et al., 2012). Moore (1990) categorizes the types of educational interactions as follows: student-student interaction, student-teacher interaction, and student interaction with curriculum. This classification is the most common model used in the design of online training. Peace of mind for students requires their active participation in the classroom (online). Hylton (2007) advises teachers to engage students in critical thinking by designing appropriate activities.

Educational achievement is the result of active student participation. In his research, King (2015) concluded that there is a high correlation between active participation and educational achievement. Korobova and Starobin (2015) have advised faculty and administrators to monitor student participation because participation plays a prominent role in learning. Assessing student participation in the learning process can help educational administrators and faculty to better manage the learning process and take the necessary educational measures if student participation is weak (Christenson et al., 2012). Since the active participation of students is an acquired trait, it can be intervened and strengthened with educational techniques (Reschly et al., 2014). Student participation should be assessed before the intervention.

The fundamental question is, "What behaviors do active students exhibit?" In traditional classes, active participation involves students' behavioral, emotional, and cognitive responses to educational activities. Kahu (2003) believes that types of classroom participation include: enthusiasm for learning, a sense of belonging to classmates, deep learning, self-regulation, and communication with classmates. There are various methods for estimating student participation; for example, observing their activities in the classroom, executing a questionnaire, and reviewing the records in the university's virtual education system. Behavioral and educational participation can be assessed by the amount of time spent doing homework. According to Balfanz and Byrnes (2003), student acceptance in each course and their attendance can also indicate student participation. Of course, cognitive and emotional involvement is not easily observed and evaluated. Skinner et al. (2009), for example, has asked these questions: 
1. How do you know if students feel a sense of belonging in the classroom?

2. Do classmates and teachers care about them?

3. Do they feel supported?

4. What is the connection between their efforts and future goals?

As mentioned earlier, there are various ways to evaluate student participation. Among these, self-expression through a questionnaire is the most common and appropriate method. Reschly et al. (2020) argue that students' perceptions of their own participation should be important to researchers, faculty, and administrators. Recent research has also demonstrated that supportive class environments enhance student efficacy and involvement and improve student outcomes (Patrick et al., 2007). Teacher and administrative facilitation of student involvement has been described as relevant to fostering academic commitment and self-determination and positive outcomes both across gender and cross-culturally (Gibson \& Bejinez, 2002; Levesque et al., 2004). Perhaps educators believe that they have provided the best facilities for students; but if students do not have such an understanding, the actions of principals and the teaching methods of professors are questionable. Shernoff et al. (2013) claim that previous research has shown that active student participation in the learning process is a prerequisite for learning and its sustainability. There is evidence that active student participation is one of the strongest predictors of academic achievement (Green et al., 2012).

Therefore, a participatory learning environment has many benefits for students, such as deeper learning, higher grades, and greater success (Shernoff, 2016). There are various ways to enhance student participation including: 1. Designing meaningful class assignments, 2. Supporting student empowerment, 3. Increasing student empowerment, 4. Strengthening positive relationships with peers, and 5. Creating a positive relationship between students and teachers (Pino-James, 2018). A meaningful classroom activity refers to an activity that has educational value and is attractive to the student. It means the ability of students to be independent in the classroom; this also means that they can increase their literacy without dependence on the teacher. Ability indicates a sense of ability to succeed in class activities (Deci \& Ryan, 2000). Baumeister and Leary (1995) stated that positive relationships with peers lead to students' socialization. A positive relationship between students and teachers refers to a relationship in which the students feel that there are a sympathizer and supportive for them.

Moving from traditional face-to-face learning environment to online contexts, scholars have recently proposed constructs and measurements to understand student engagement, particularly in an online environment. Hew (2015, p. 426) organizes the model of online student engagement around self-determination theory that postulates the individual to have three essential needs: "autonomy, relatedness, and competence." Autonomy corresponds to the behavioral aspect (doing); relatedness corresponds to the affective or emotional aspect (feeling); and competence corresponds to the cognitive aspects (thinking) (Hew, 2015). Based on his model, Hew (2015) suggests the guideline to effectively engage online students: "course information, course sources, interaction, active learning, frequent monitoring of learning, and making meaningful connections."

In a similar vein, Dixson (2015) applied the online student engagement scale proposed by Handelsman et al. (2005) to measure self-reported student engagement with an online tracking system of student behavior. The researchers found that online student engagement and achievement positively and significantly correlates with student behaviors in an online course. It indicates that the given measurement tool for online student engagement has the potential to assess student engagement in online learning.

Engagement is linked to several important issues in higher education such as participation in educational activities, learning outcomes, and student achievement. Engagement is a multifaceted concept and examined under different dimensions in the literature. Chakraborty (2014) defines the concept of online engagement with behavioral, collaborative, emotional, social, and cognitive dimensions.

But how can we measure the students' level of engagement in online classes? Much research has been done on the active participation of students in traditional education and online education (Centner, 2014; Schreiber \& Yu, 2016). In these studies, the relationship between active participation and design and delivery of education, technical support, self-regulation, self-management, academic satisfaction, perseverance, student performance, and academic achievement has been considered. A review of various researches indicates that there are four questionnaires to measure the active participation of students:

- Scale of characteristics of active participation in distance education (Roblyer \& Wiencke, 2004) 
- Class survey on active participation (Ouimet \& Smallwood, 2005)

- Questionnaire of active participation of students in each lesson (Handelsman et al., 2005)

- Scale of student participation in online class (Urquhart \& Weir, 2010)

The first questionnaire asks students about the behavior of other students and how they interact. Given that many behaviors are not visible in the online classroom; this questionnaire does not seem acceptable. The second questionnaire, or the class survey questionnaire, asks students to report on their behaviors in a particular class and outside that class, but this questionnaire has two forms: the student form and the teacher form. The teacher form emphasizes the importance of the factors reported by the students. Comparing these two forms helps the researcher to identify discrepancies. This questionnaire is designed for face-to-face training. The third questionnaire (Active Student Participation Questionnaire in each lesson) has four constructs of skills, emotions, interaction, and performance. Attention to the criterion of students' emotional participation (interaction with the curriculum, interaction with other students and professors) is consistent with the theory of constructivism which is one of the strengths of this questionnaire. However, this questionnaire has been prepared for face-to-face classes and does not fully comply with online training. The fourth questionnaire defines participation including attitudes, thinking, behavior, and communication with others.

From the above description, it can be seen that students' engagement plays a big role in face-to-face context of learning, but we have a problem to assess it when learning online during the pandemic. Therefore, this article, will describe students engagement in online learning during the pandemic. According to Dixson (2015), participation includes attitudes, thinking, behavior, and communication with others. Active participation refers to the time, energy, thinking, effort, and to some extent the student's sense of the learning process. Thus, the "Active Participation Scale in Online Education" seeks to do what students do; assess their sense of learning and their relationship to the content of the lesson, the teacher, and other students in terms of skills, class participation, performance, and emotions. This questionnaire has been used in the present study.

\section{Methodology}

\subsection{Research Design}

The study used a correlational design to address the research question using Dixon's Online Student Engagement Scale and a researcher-created achievement exam. The questionnaire was developed in 2015 and comprises four categories and 19 items on a seven-point Likert scale. In 2020, the questionnaire was modified with Google Form and distributed to 297 students enrolled in general English courses via a university LMS. The second instrument was a 40item test of reading comprehension developed by the researcher. The examination was created on the basis of reading theories and was given as a final exam. The one-sample t-test findings indicated that students' achievement and engagement levels are adequate.

\subsection{Participants}

Participants in this study were 297 students of general language course at Birjand University and were between 19 and 23 years old. In order to collect data, questionnaires and English language tests were sent to their virtual education page. 206 students answered the questionnaires completely.

\subsection{Instruments}

To answer the research questions, the questionnaire "Active participation in online education" and the test "Reading and comprehension" in English were used. This questionnaire was designed by Dixson in 2015; however, after reviewing, no record of the original or its translation was found in Iranian scientific-research journals. Therefore, the researcher translated it. The reverse translation of this questionnaire was done by one of the respected professors. This questionnaire has 4 structures and 19 items. Structures are skills, emotions, participation, and performance. The second tool of this research is the "Reading and Comprehension" test in English. This test has 40 questions and the researcher has designed it based on theoretical studies related to the mentioned skill and has used the help of 5 professors to check the compliance of the test with scientific theories and confirm its content. This test was administered at the end of the semester as a final test to the students.

\subsection{Data Collection Procedures}


The English language test was uploaded and performed as a final exam in the university's virtual education system such as frequencies and percentages. In fact, for the purpose of the first research question, such descriptive statistics as mean, median, and mode (among other things) were used and reported to help gain an understanding of the extent to which EFL learners' level of engagement and performance. The questionnaire of this research was designed using Google Form and sent to 297 students who had a general language course in the first half of the academic year 1399 through the university's virtual education system, and they were asked to rate their agreement or disagreement based on the given options from 1 to 7. 206 students answered the questionnaire. The answers to 22 of the questionnaire were distorted. For example, all items were given one answer or their answers were one in the middle of duplicates. Therefore, their answers were discarded. A total of 184 responses were analyzed along with the language scores of the same individuals.

\subsection{Data Analysis}

The analysis of the data in the present study took place mainly through descriptive statistics. The skill structure consists of items $1,3,4,5,7$, and 6 . The structure of emotions includes items $2,8,9,10,11$, and 19 . The participation structure consists of items $12,13,14,17$, and 18. The function structure includes items 15 and 16 . This questionnaire is designed on a 7-point Likert scale. The 7 degrees of scale are: never (in my case) true (1); Most of the time (in my case) it is not true (2); Sometimes (in my case) it is not true. (3) I do not know (4); Sometimes (in my case) it is true (5); Most of the time (in my case) it is true. (6); It is always (in my case) true (7).

\section{Results}

As can be seen in Table 1, the reliability of the Active Participation Questionnaire is 0.93 , which indicates a high reliability and indicates its appropriateness.

Table 1. Reliability statistics for online student engagement scale

\begin{tabular}{lll}
\hline Cronbach's Alpha & Cronbach's Alpha Based on Standardized Items & Number of Items \\
\hline 0.93 & 0.93 & 19 \\
\hline
\end{tabular}

Reading skills are defined as the process of receiving and interpreting written coded information in a language (Urquhart \& Weir, 2010). As shown in Table 2, the reliability of the test is 0.86 ; this degree of reliability, especially in the case of academic achievement tests, is very high and indicates its appropriateness.

Table 2. Reliability statistics for online reading comprehension test

\begin{tabular}{lll}
\hline Cronbach's Alpha & Cronbach's Alpha Based on Standardized Items & Number of Items \\
\hline 0.86 & 0.87 & 40 \\
\hline
\end{tabular}

As mentioned earlier, the English language test in this study had 40 questions and each question was assigned a score of 1 . According to the information in Table 3, the lowest score is 8, the highest score is 39 and the average of the group is 30.67. Of course, given that English is an easy subject for engineering students; this seems like a normal average. The results of this test are presented in Table 4.

Table 3. Descriptive statistics for English test

\begin{tabular}{llllll}
\hline & Number & Minimum & Maximum & Mean & Std. Deviation \\
\hline English & 184 & 8.00 & 39.00 & 30.67 & 6.49 \\
\hline Valid N(list wise) & 184 & & & & \\
\hline
\end{tabular}


Table 4. One-sample test for English test

\begin{tabular}{lllllcc}
\hline Test Value $=28$ & \multicolumn{5}{c}{$95 \%$ Confidence Interval of the Difference } \\
\hline & $\mathrm{T}$ & Df & Sig. (2-tailed) & Mean difference & Lower & Upper \\
\hline English & 5.58 & 183 & 0.000 & 2.67 & 1.72 & 3.61 \\
\hline
\end{tabular}

As mentioned in the research tools section, this questionnaire has 19 items and its scale is 7 points. According to the information in Table 5, the lowest score is 19 and the highest score is 133 and the group average is 93.69. The average is slightly less than 70 percent of the total score. If $50 \%$ of the total score of the questionnaire can be considered as an acceptable indicator of class participation, it can be said that students in this research sample reported acceptable class participation.

Table 5. Descriptive statistics online student engagement scale

\begin{tabular}{llllll}
\hline & Number & Minimum & Maximum & Mean & Std. Deviation \\
\hline Engagement & 184 & 19.00 & 133.00 & 93.69 & 19.800 \\
\hline Valid N(list wise) & 184 & & & & \\
\hline
\end{tabular}

Table 6. One-sample test for online student engagement scale

\begin{tabular}{lllllll}
\hline Test Value $=90$ & \multicolumn{6}{c}{$95 \%$ Confidence Interval of the Difference } \\
\hline & $\mathrm{T}$ & Df & Sig. (2-tailed) & Mean difference & Lower & Upper \\
\hline Engagement & 2.52 & 183 & 0.012 & 3.69 & 0.81 & 6.570 \\
\hline
\end{tabular}

As mentioned earlier, in this study the researcher tries to examine the relationship between active classroom participation and learning English. This research is of correlation type and correlation coefficient method is used to analyze the results. In Tables 1 and 2, the reliability of research tools was reported. After ensuring the validity of the research tools, the researcher reports the correlation between them. Table 7 shows that the correlation between active participation in online class and learning English is $0.02(\mathrm{p}=0.75, \mathrm{R}=0.02)$. In other words, there is no significant relationship between these two variables.

Table 7. Correlation between English achievement and engagement

\begin{tabular}{llll}
\hline & & English & Engagement \\
\hline English & Pearson Correlation & 1 & 0.024 \\
\hline Sig. (2-tailed) & & 0.75 \\
\hline Number & 184 & 184 \\
\hline
\end{tabular}

The lack of a significant relationship between academic achievement and active participation in online classes is different from the findings of foreign research (there is no research report on online class participation in Iran). This result is in contradiction with the theories of education. For example, the theory of "communication language teaching" is based on the principle of participation. Probably the reason for this contradiction should be related to the example 
of the present study. Therefore, care should be taken in the distribution of English language course grades. The graph of the distribution of scores is shown in Figure 1.

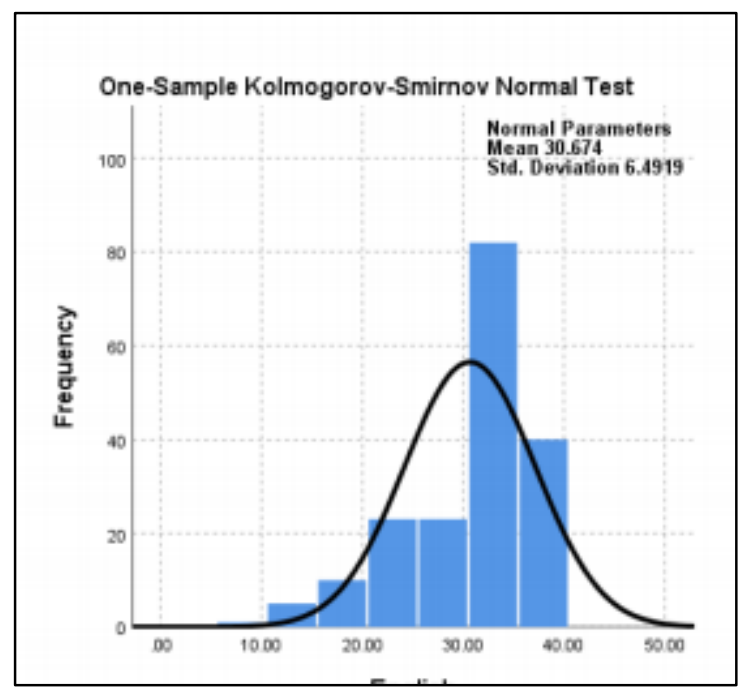

Fig 1. One-sample Kolmogorov-Smirnov normal test

Carefully in Figure 1, a kind of asymmetry can be observed and it can be claimed that the scores have elongation. The results of the analysis are reported in Table 8.

Table 8. Simultaneous quantile regression

\begin{tabular}{lc}
\hline Number of observations & 184 \\
\hline Boot strap (20) SEs & Pseudo R2=0.02 \\
\hline English $\mid$ Coef $\mid$ Std. Err. $|\mathrm{t}>| \mathrm{t} \mid[95 \%$ Conf. Interval & \\
\hline Q25 & \\
\hline Engagement & \\
\hline cons 17.174 .703 .650 .007 .8826 .45 \\
\hline
\end{tabular}

As can be seen in Table 8, the "T" index is statistically significant. Therefore, it can be argued that there is a significant relationship between active participation and learning English in students with high scores. $(t=2.19, \mathrm{P}=0.03)$. In Table 8 , it is also indicated that for every one point in class participation increase, there is an increase of 0.10 in the English language score.

\section{Discussion}

In this section, research questions are answered. The first research question is as follows:

1. Are students' academic progresses in English satisfactory?

To answer this question, the one sample T-test was used. According to the results, it can be claimed that the academic achievement of students in this study is satisfactory. Inferential statistics is used to prove this claim. Koda (2005) believes that comprehension occurs when the reader extracts the information contained in the text and integrates it 
with his previous information. Linguistic processes of reading skills include lexical and grammatical knowledge (Perfetti, 1999). English language educators consider reading and comprehension skills to be a combination of subskills. Alderson (2000) describes these fine skills as remembering the meaning of words; understanding the meaning of words based on text; understanding in-text and out-of-text references; inferencing from text; searching and retrieving specific information; understanding grammatical relationships; and recognizing the author's style and tone.

In the present single sample test, we have assumed a standard score of 28 , equal to $70 \%$ of the total test score. According to the evidence in Table 4, the value of $t$ is statistically significant : $(\mathrm{t}(183)=5.58, \mathrm{P}=.00)$. Therefore, the null hypothesis is rejected and the research hypothesis is confirmed and the claim that students' academic achievement is satisfactory is acceptable.

The second research question is:

2. To what extent do students perceive class participation?

To prove this claim, one sample T-test was used. The results of this test are presented in Table 6. In the present single sample test, we have assumed a standard score of 90 . This score is about $67 \%$ of the total score of the questionnaire and has a default of 50\%. According to the evidence in Table 6 , the value of $t$ is statistically significant $(\mathrm{t}(183)=2.52$, $\mathrm{P}=.01$ ) Therefore, the null hypothesis is rejected and the alternative hypothesis is confirmed, and it can be said that the students' perception of class participation is as expected.

The third research question is as follows:

3. Is there a significant relationship between active participation and academic achievement in the online English class?

Due to the fact that students have a good knowledge of English in the last decade, obtaining high scores in the present study seems normal. On the other hand, the analysis of "correlation coefficient" depends on the grade point average of the test takers, and in cases where the students' GPA is high, the correlation coefficient does not give completely accurate results. Therefore, the researcher decided to use the quantile regression method to measure the hypothesis of a different effect of class participation on students above average.

These findings help us to accept that active participation in the online classroom applies to diligent students. Probably such students have been able to adapt better to online education than others. On the other hand, if the researchers focus on educational norms and emphasize the "average" index of scores, the answer to the third question of the present study is negative; That is, there is no significant relationship between class participation and academic achievement.

There are various reasons for this subject. Online education was not optional in the present study and students did not have sufficient motivation, skills, and tools for this method of education. Maybe that's why students are so scared and anxious. This fear and anxiety may lead to academic dissatisfaction or self-loathing. On the other hand, educators, like students, did not have the necessary skills for online education and used their previous teaching method without any modifications in online education. This method of teaching has caused a lot of trouble for the teachers and has caused their dissatisfaction. Weaknesses in technical infrastructure (problems with the Internet, lack of facilities such as computers, laptops, tablets, etc.) and weaknesses in the design of education can also discourage students and their educators. The combination of these factors can harm the educational process and reduce the active participation of students. Song et al. (2004) valued the role of online classroom design in students' success. In the online educational plan, the element of interaction between students with the course materials and interaction with the teacher and students' interaction with each other (possibility of discussion) should be addressed. Unfortunately, the evidence suggests that this issue has been neglected. For example, Poll and Weller (2014) have proposed six strategies for this type of education:

1. Creating student groups,

2. Explaining the objectives of the lesson by the teacher or educational institution,

3. Using interactive tools in educational systems,

4. Encouraging dialogue between students and educators,

5. Provide appropriate and timely feedback from the teachers, and 


\section{Create a student-centered environment.}

As far as the author is aware, the virtual education system of many universities uses the Moodle platform. The platform has audio and video communication tools and a forum. Using these tools can enhance education and thus increase active student participation. But the fundamental question is to what extent professors and students are familiar with these tools or to what extent they have had the time and opportunity to use these tools. Did the number of students in the class meet the required standards? For example, the e-learning system in Iranian higher education (2010) recommends that the number of students in e-learning classes should be between 15 and 20. Of course, as mentioned earlier, e-learning has become mandatory on its current scale. Therefore, it is natural that students and teachers do not have enough motivation to adapt to this method of education. As Cox and Egbue (2014) have suggested, turning faceto-face training into online training requires a lot of planning and training for planners, faculty, and students. In addition, it requires a lot of time.

\section{Conclusion}

Based on the data obtained, it can be concluded that students face various difficulties concerning online engagement. Apparently, in a pandemic-driven volatile, uncertain, complex, and ambiguous learning environment, strong selfefficacy beliefs contribute to more study engagement. The purpose of this study was to estimate the academic achievement of students in general language courses, their perception of class participation and the relationship between active participation and learning English in the online classroom. The results showed that students' academic achievement is satisfactory and their perception of class participation is acceptable. The relationship between class participation and language learning is significant for strong students, but in the case of intermediate and weak students, there is no significant relationship between these two variables. A questionnaire was used to assess the level of student participation. Technicians know that the questionnaire is based on self-declaration and there is a possibility of measurement error in this tool. For example, some students may overestimate their participation. Of course, the necessity of online education and classroom density may also have an adverse effect on students' self-expression.

Additionally, the findings on the relationship of increasing student involvement in educational planning and likelihood of graduation suggest one possible method that could be employed by faculty personnel would be to actively seek student input and participation throughout the tertiary experience. This process would involve more than the required involvement of students in course selection to a concerted effort to solicit student input and participation in all stages of educational planning. Possible methods for soliciting student input could be the use of the student involvement survey or other recent multidimensional measures of student engagement (Wang et al., 2011).

\subsection{Limitations}

The data were obtained from one university which accommodates over 10.000 students from urban and countryside areas. The sample may not represent the online student engagement in other universities.

\section{Acknowledgments}

Dear students who completed and sent the questionnaires. In addition, respected professors encouraged students to participate in this research and effectively helped the author. She assumes that she appreciates the good cooperation of these loved ones.

\section{References}

Alderson, J. C. (2000). Assessing reading. Cambridge: Cambridge University Press.

Alhazzani, N. (2020). MOOC's impact on higher education. Soc. Sci. Humanit, 2(1). https://doi.org/10.1016/j.ssaho.2020.100030

Al Kurdi, B., Alshurideh, M., \& Salloum, S. A. (2020). Investigating a theoretical framework for e-learning technology acceptance. Int. J. Electr. Comput. Eng, 10(6), 6484-6496. doi:10.11591/ijece.v10i6.pp64846496

Allen, T. O., \& Zhang, Y. (2016). Dedicated to their degrees. Community College Review, 44(1), 70-86. https://doi.org/10.1177/0091552115617018 
Badrkhani, P. (2021). How a catastrophic situation turns into an exceptional opportunity: Covid-19 pandemic in Iran and challenges of online education for new English language educators. Interactive Learning Environments. doi: 10.1080/10494820.2021.1956545

Balfanz, R., \& Byrnes, V. (2019). Early warning indicators and intervention systems: State of the field. In J. Fredricks, A. Reschly, \& S. Christenson (Eds.), Handbook of student engagement interventions. London, UK.

Baumeister, R. F., \& Leary, M. R. (1995). The need to belong: Desire for interpersonal attachments as a fundamental human motivation. Psychological Bulletin, 117(3), 497-529. https://doi.org/10.1037/0033-2909.117.3.497

Bigatel, P. M., Ragan, L. C., Kenan, S., May, J., \& Redmond, B. F. (2012). The identification of competencies for online teaching success. Journal of Asynchronous Learning Networks, 16(1), 59-77. https://files.eric.ed.gov/fulltext/EJ971040.pdf

Centner, T. J. (2014). Structuring a distance education program to attain student engagement. North American Colleges and Teachers of Agriculture Journal, 58(3), 230-235. https://www.jstor.org/stable/nactajournal.58.3.230

Chakraborty, M., \& Nafukho, F. M. (2014). Strengthening student engagement: what do students want in online courses? European Journal of Training and Development, 38(9), 782-802. https://doi.org/10.1108/EJTD-112013-0123

Christenson, S. L., Reschly, A. L., \& Wylie, C. (2012). Handbook of research on student engagement. Boston, MA: Springer Science \& Business Media. doi: https://doi.org/10.1007/978-1-4614-2018-7

Connell, J. P., Halpern-Felsher, B. L., Clifford, E., Crichlow, W., \& Usinger, P. (1995). Hanging in there: behavioral, psychological, and contextual factors affecting whether African American adolescents stay in high school. Journal of Adolescent Research, 10(1), 41-63. https://doi.org/10.1177/0743554895101004

Cox, E., \& Egbue, O. (2014). Resistance to change in academia: Impacts and long-term implications for engineering education. Proceedings of the 2014 ASEE Midwest Section Conference, Fort Smith, Arkansas.

Deci, E., \& Ryan, R. (2000). The "what" and "why" of goal pursuits: Human needs and the self-determination of behavior. Psychological Inquiry, 11(4), 227-268. https://doi.org/10.1207/S15327965PLI1104_01

Dennen, V. P., Darabi, A. A., \& Smith, L. J. (2007). Instructor-learner interaction in online courses: The relative perceived importance of particular instructor actions on performance and satisfaction. Distance Education, 28(1), 65-79. https://doi.org/10.1080/01587910701305319

Dixson, M. D. (2015). Measuring student engagement in the online course: The online student Engagement scale (OSE), Online Learning, 19(4), 1-15. https://doi.org/10.24059/olj.v19i4.561

Farooq, F., Rathore, F. A., \& Mansoor, S. N. (2020). Challenges of online medical education in Pakistan during COVID-19 pandemic. J. Coll. Physicians Surg. Pak, 30(6), 67-69. doi: 10.29271/jcpsp.2020.Supp1.S67

Fisher, K. (2010). Online student engagement: CCSSE finds enrollment status and online experience are key. Community College Week. https://www.thefreelibrary.com/Online+student+engagement\%3A+CCSSE+finds+enrollment+status+and+ online+...-a0227361934

Gibson, M., \& Bejinez, L. (2002). Dropout prevention: How migrant education supports Mexican youth. Journal of Latinos and Education, 1(3), 155-175. https://doi.org/10.1207/S1532771XJLE0103_2

Green, J., Liem, G. A. D., Martin, A. J., Colmar, S., Marsh, H. W., \& McInerney, D. (2012). Academic motivation, self-concept, engagement, and performance in high school: Key processes from a longitudinal perspective. Journal of Adolescence, 35(5), 1111-1122. https://doi.org/10.1016/j.adolescence.2012.02.016

Handelsman, M. M., Briggs, W. L., Sullivan, N., \& Towler, A. (2005). A measure of college student course engagement. The Journal of Educational Research, 98(3), 184-192. https://doi.org/10.3200/JOER.98.3.184192 
Hew, K. F. (2015). Towards a model of engaging online students: lessons from MOOCs and four policy documents. International Journal of Information and Education Technology, 5(6), 425-431. https://doi.org/10.7763/IJIET.2015.V5.543

Hoffman, B., \& Ritchie, D. (1997). Using multimedia to overcome the problems with problem-based learning. Instructional Science, 25, 97-115. https://doi.org/10.1023/A:1002967414942

Horn, L., Peter, K., \& Rooney, K. (2002). Profile of undergraduates in U.S. postsecondary institutions: 1999-2000. Statistical analysis report. National Postsecondary Student Aid Study (NCES2002-168). National Center for Education Statistics. https://nces.ed.gov/pubs2002/2002168.pdf

Horn, L. J., \& Premo, M. D. (1995). Profile of undergraduates in U.S. postsecondary education institutions: 1992-93. With an essay on undergraduates at risk. Statistical analysis report. (NCES 96-237). National Center for Education Statistics. https://files.eric.ed.gov/fulltext/ED392852.pdf

Hylton, M. E. (2007). Facilitating online learning communities: A comparison of two discussion facilitation techniques. Journal of Technology in Human Services, 25(4), 63-78. https://doi.org/10.1300/J017v25n04_04

Kahu, E. R. (2003). Framing student engagement in higher education. Stud. High. Educ, 38(5), 758-773. https://doi.org/10.1080/03075079.2011.598505

Khan, A., Egbue, O., Palkie, B., \& Madden, J. (2017). Active learning: Engaging students to maximize learning in an online course. Electronic Journal of E-Learning, 15(2), 107115. https://files.eric.ed.gov/fulltext/EJ1141876.pdf

King, R. B. (2015). Sense of relatedness boosts engagement, achievement, and well-being: A latent growth model study. Contemporary Educational Psychology, 42, 26-38. https://doi.org/10.1016/j.cedpsych.2015.04.002

Koda, K. (2005). Insights into second language reading: A cross- linguistic approach. Cambridge, UK: Cambridge University Press.

Korobova, N., \& Starobin, S. S. (2015). A comparative study of student engagement, satisfaction, and academic success among international and American students. Journal of International Students, 5(1), 72-85. https://files.eric.ed.gov/fulltext/EJ1052833.pdf

Kuh, G. D. (2003). What we're learning about student engagement from NSSE: Benchmarks for effective educational practices. Change, 35(2), 24-32. https://doi.org/10.1080/00091380309604090

Layne, M., Boston, W. E., \& Ice, P. (2013). A longitudinal study of online learners: Shoppers, swirlers, stoppers, and succeeders as a function of demographic characteristics. Online Journal of Distance Learning Administration, 16(2), 1-13. https://www.westga.edu/ distance/ojdla/summer162/layne_boston_ice162.pdf

Levesque, C., Zuehlke, N., Stanek, L., \& Ryan, R. (2004). Autonomy and competence in German and U.S. university students: A comparative study based on self-determination theory. Journal of Educational Psychology, 96(1), 68-84. https://selfdeterminationtheory.org/SDT/documents/2004_LevesqueZueStaRyan.pdf

Lewis, A. D., Huebner, E. S., Malone, P. S., \& Valois, R. F. (2011). Life satisfaction and student engagement in adolescents. J. Youth. Adolesc, 4(3), 249-262. doi: 10.1007/s10964-010-9517-6

Lim, D. H., \& Morris, M. L. (2009). Learner and instructional factors influencing learning outcomes within a blended learning environment. Educational Technology \& Society, 12(4), 282-293. http://www.anitacrawley.net/Resources/Articles/LimMorris(2009).pdf

Loh, C., Wong, D. H., Quazi, A., \& Kingshott, R. P. (2016). Re-examining students' perception of e-learning: An Australian perspective. International Journal of Educational Management, 30(1), 129-139. http://hdl.handle.net/20.500.11937/39370

Martins, J., \& Nunes, M. B. (2016). The temporal properties of e-learning: An exploratory study of academics' conceptions. International Journal of Educational Management, 30(1), 2-19. https://doi.org/10.1108/IJEM04-2014-0048 
Maslach, C., \& Leiter, M. P. (1997). The truth about burnout: How organizations cause personal stress and what to do about it. Hoboken, NJ: Wiley.

Mitra, S., \& Le, K. (2019). The effect of cognitive and behavioral factors on student success in a bottleneck business statistics course via deeper analytics. Communications in Statistics-Simulation and Computation, 1-30. doi.org/10.1080/03610918.2019.1700279

Moore, M. G. (1990). Recent contributions to the theory of distance education. Open Learning, 5(3), 10-15. https://doi.org/10.1080/0268051900050303

Muller, J. (2020). Penetration of leading social networks in Indonesia as of 3rd quarter 2019. Statista. https://www.statista.com/statistics/284437/indonesia-social-network-penetration/

Nassoura, A. B. (2020). Measuring students' perceptions of online learning in higher education. International Journal of Science \& Technology Research, 9(4), 1965-1970. https://www.ijstr.org/final-print/apr2020/MeasuringStudents-Perceptions-Of-Online-Learning-In-Higher-Education.pdf

Nickerson, L. A., \& Shea, K. M. (2020). First-semester organic chemistry during COVID-19: Prioritizing group work, flexibility, and student engagement. J. Chem. Educ, 97, 3201-3205. doi.org/10.1021/acs.jchemed.0c00674

Ouimet, J. A., \& Smallwood, R. A. (2005). CLASSE: The class-level survey of student engagement. Journal of Assessment Update: Progress, Trends, and Practices in Higher Education, 17(6), 13-15. https://eric.ed.gov/?id=EJ790789

Patrick, H., Ryan, A., \& Kaplan, A. (2007). Early adolescents' perceptions of the classroom social environment, motivational beliefs, and engagement. Journal of Educational Psychology, 99(1), 83-98. https://doi.org/10.1037/0022-0663.99.1.83

Perfetti, C. A. (1999). Comprehending written language: A blueprint of the reader. In C. M. Brown \& P. Hagoort (Eds.), The neurocognition of language (pp. 167-208). Oxford, England: Oxford University Press.

Pérez-Pérez, M., Serrano-Bedia, A. M., \& García-Piqueres, G. (2020). An analysis of factors affecting students' perceptions of learning outcomes with Moodle. J. Furth. High. Educ., 44(8), 1114-1129. https://doi.org/10.1080/0309877X.2019.1664730

Perets, E. A., Chabeda, D., Gong, A. Z., Huang, X., Fung, T. S., \& Ng, K. Y. (2020). Impact of the emergency transition to remote teaching on student engagement in a Non-STEM undergraduate chemistry course in the time of COVID-19. J. Chem. Educ, 97(9), 2439-2447. https://doi.org/10.1021/acs.jchemed.0c00879

Phillips, N. (2005). Forced learning theory. Training: the magazine of manpower and management development, $42(6), 46$.

Pino-James, N. (2018). Evaluation of a pedagogical model for student engagement in learning activities. Educational Action Research, 26(3), 456-479. doi: 10.1080/09650792.2017.1354771

Poll, K., Widen, J., \& Weller, S. (2014). Six instructional best practices for online engagement and retention. Journal of Online Doctoral Education, 1(1), 56-72. https://ecommons.luc.edu/cgi/viewcontent.cgi?article=1030\&context=english_facpubs

Qureshi, F., Khawaja, S., \& Zia, T. (2020). Mature undergraduate students' satisfaction with online teaching during COVID-19. European Journal of Education Studies, 7(12), 456-475. doi: 10.46827/ejes.v7i12.3440

Reschly, A., Appleton, J. J., \& Pohl, A. (2014). Best practices in fostering student engagement. In A. Thomas \& P. Harrison (Eds.), Best practices in school psychology (pp. 37-50). Bethesda, MD: National Association of School Psychologists.

Reschly, A. L., Pohl, A., Christenson, S. L., \& Appleton, J. J. (2017). Engaging adolescents in secondary schools. In B. Schultz, J. Harrison, \& S. Evans (Eds.), School mental health services for adolescents (pp. 45-77). New York: Oxford University Press.

Reschly, A. L., Pohl, A. J., \& Christenson, S. L. (2020). Editors student engagement effective academic, behavioral, cognitive, and affective Interventions at school. Switzerland: Springer Nature. 
Roblyer, M. D., \& Wiencke, W. R. (2004). Exploring the interaction equation: Validating a rubric to assess and encourage interaction in distance courses. Journal of Asynchronous Learning Networks, 8(4), 25-37. https://olj.onlinelearningconsortium.org/index.php/olj/article/view/1808/639

Rose, M., \& Moore, A. (2019). Student Retention in Online Courses: University Role. Online Journal of Distance Learning Administration, 22(3), 1-14. https://eric.ed.gov/?id=EJ1228760

Schaufeli, W. B., Martínez, I. M., Pinto, A. M., Salanova, M., \& Bakker, A. B. (2002). Burnout and engagement in university students: a cross- national study. J. Cross. Cult. Psychol., 33(5), 464-481. https://doi.org/10.1177/0022022102033005003

Schreiber, B., \& Yu, D. (2016). Exploring student engagement practices at a South African university: Student engagement as reliable predictor of academic performance. South African Journal of Higher Education, 30(5), 157-175. https://doi.org/10.20853/30-5-593

Seymour, E., \& Hewitt, N. M. (1997). Talking about leaving: why undergraduates leave the sciences. United States of America: Westview Press.

Sheridan, K., \& Kelly, M. A. (2010). The indicators of instructor presence that are important to students in online courses. MERLOT Journal of Online Learning and Teaching, 6(4), 767-779. https://jolt.merlot.org/vol6no4/sheridan_1210.htm

Shernoff, D. J. (2013). Optimal learning environments to promote student engagement. New York: Springer.

Shernoff, D. J., Ruze, E., \& Sinha, S. (2016). The influence of the high school classroom environment on learning as mediated by student engagement. School Psychology International, 38(2), 201-218. https://doi.org/10.1177/0143034316666413

Shrestha, E., Mehta, R. S., Mandal, G., Chaudhary, K., \& Pradhan, N. (2019). Perception of the learning environment among the students in a nursing college in Eastern Nepal. BMC Med. Educ., 19, 382. https://doi.org/10.1186/s12909-019-1835-0

Skinner, E. A., Kindermann, T. A., \& Furrer, C. J. (2009). A motivational perspective on engagement and disaffection: Conceptualization and assessment of children's behavioral and emotional participation in academic activities in the classroom. Educational and Psychological Measurement, 69(3), 493-525. https://doi.org/10.1177/0013164408323233

Song, D., Oh, E., \& Rice, M. (2017). Interacting with a conversational agent system for educational purposes in online courses. Proceedings of the 10th International Conference on Human System Interaction (pp. 78-82). Ulsan, South Korea: IEEE. doi: 10.1109/HSI.2017.8005002

Stocker, B. L. (2018). Transitioning from on-campus to online in a master of science nursing program: A comparative study of academic success. American Journal of Distance Education, 32(2), 113-130. https://doi.org/10.1080/08923647.2018.1443371

Stoessel, K., Ihme, T. A., Barbarino, M. L., Fisseler, B., \& Stürmer, S. (2015). Sociodemographic diversity and distance education: Who drops out from academic programs and why? Research in Higher Education, 56(3), 228-246. https://doi.org/10.1007/s11162-014-9343-x

Taplin, M. (2000). Problem-based learning in distance education: Practitioners' beliefs about an action learning project. Distance Education, 21(2), 278-299. https://doi.org/10.1080/0158791000210206

Tobias, S. (1990). They're not dumb, they're different: stalking the second tier. Tucson, Ariz. (6840 E. Broadway Blvd., Tucson 85710-2815): Research Corp.

Umbach, P., \& Wawrzynski, M. R. (2005). Faculty do matter: The role of college faculty in student learning and engagement. Research in Higher Education, 46(2), 153-184. https://doi.org/10.1007/s11162-004-1598-1

Urquhart, A. H., \& Weir, C. J. (1998). Reading in a second language: Process, product, and practice. London: Longman. 
Wagner, N., Hassanein, K., \& Head, M. (2008). Who is responsible for E-learning in higher education? A stakeholders' analysis. Educational Technology \& Society, 11(3), 26-36. http://library.oum.edu.my/oumlib/sites/default/files/file_attachments/odl-resources/4332/who.pdf

Wang, M. T., Dishion, T. J., Stormshak, E. A., \& Willett, J. B. (2011). Trajectories of family management practices and early adolescence behavioral outcomes in middle school. Developmental Psychology, 47(5), 1324-1341. https://doi.org/10.1037/a0024026

Yuan, J., \& Kim, C. (2014). Guidelines for facilitating the development of learning communities in online courses. Journal of Computer Assisted Learning, 30(3), 220-232. https://doi.org/10.1111/jcal.12042 